\title{
OVERVIEW OF THE ORGANIZATION OF CLINICAL NUTRITION IN TARTU UNIVERSITY HOSPITAL
}

\author{
LIIDIA KIISK
}

Tartu University Hospital

\begin{abstract}
The association between poor nutritional status and treatment outcomes as well as increased healthcare costs have been shown in different clinical settings. Rational health care organization including a nutrition therapy is a theme that is in the centre of attention for physicians, health promoters and social workers. The paper demonstrates the organisation of a nutrition therapy at the Tartu University Hospital where counselling of patients and the medical team have gained much attention recently. In connection with the formation of the food service at the Tartu University Hospital on 1 May 1999 new important issues of management and organisation beside specific dietology issues have gained importance in feeding patients. By today the activities of the Tartu University Hospital in the field of nutrition have been reorganised in connection with the introduction of the electronic case history in the years 2008-2009.
\end{abstract}

Keywords: organisation of dietary nutrition; nomenclature of diets; nutrition counselling

\section{THE IMPLEMENTATION OF THE DIET'S SYSTEM}

The hospital feeding treatment relied on many legal documents including norms for feeding patients and the prescribed costs of the daily food. All these documents gave norms to our activities and gave them a fixed framework with differentiated monetary and nutritional norms.

For several decades in Estonian hospitals the so-called Nomenclature of Pevzner Diets was used. Its author was professor M. I. Pevzner (1872-1952), a medical researcher, gastroenterologist from Moscow University who was also 
the founder of clinical feeding treatment and the developer of diet treatment in Russia. The use of the system of Pevzner's diets was obligatory in all the hospitals in the Republic of Estonia (Pokrovski et al. 1981). Several diets, in spite of their existence in the Pevzner nomenclature, did not have a reason for such a detailed implementation. In numeration 1-15 of the classification of Pevzner's diets together with subgroups was not rational for practical use and gave no information. The feedback from the doctors of clinics showed that in the menus of the patients, having acute diseases of the digestive tract, there was too little choice of foods and nutrition which was not justified.

Since 1995 in the Maarjamõisa Hospital the implementation of the new integrated diet system has started to guarantee optimal and adequate diet treatment for the patients in the hospital. The New System and nomenclature of new modern treatment diets was used in Tartu University Clinics in Tartu since 1995-1997. This new nomenclature of diets has been developed in the hospital on the basis of theoretical and practical experience obtained over several years of co-operation with medical scientists from different fields of specialisation.

In connection with the formation of the food service at the Tartu University Hospital on 1 May 1999 new important issues of management and organisation beside specific dietology issues have gained importance in feeding patients. By today the activities of the Tartu University Hospital in the field of nutrition have been reorganised in connection with the introduction of the electronic case history in the years 2008-2009. The common system of diets for treatment has been implemented in all the hospitals and care centres in the whole republic (Regulation No 131. Estonian Ministry of Social Affairs. Tervisekaitsenõuded toitlustamisele tervishoiu- ja hoolekandeasutuses 2002).

Two main methods have been accepted in nutrition research: the food frequency questionnaire (FFQ) and the 3-day nutrition diary. We implemented a special FFQ compiled by the Centre of Physical Anthropology at the University of Tartu. The FFQ consists of socio-economic, physical activity and nutrition research (Kiisk et al. 2010).

The food energy and the content of nutrients of ready-made foods and menus are calculated on the basis of the nutrition program of the Institute of Research Development (NutriData Food Composition Database 2014). All the above mentioned changes in dietology have been checked by the treating doctors and the dietologists together when monitoring the patients. 


\section{THE HANDBOOK FOR DOCTORS AND NURSES IN COUNSELLING PATIENTS}

Dietitian Liidia Kiisk with co-authors has worked out a systematized list of diets and compiled a collection of articles which takes into consideration contemporary principles of feeding treatment. The names and indications of the nomenclature of diets and the respective recommendations for the consumption of daily energy and basic nutrients are given in the Estonian handbook "Ravitoitlustamine". Treatment diets" (Kiisk et al. 2002). In the nomenclature of diets ordinary food and light groups of diet food are given. Each subgroup has a detailed characterization, the average content of basic nutrients and the indication for their use in the case of a certain disease. The handbook contains 227 recipes together with the complication of foods and nutrients. All the diet foods for treatment have been presented in the form of the examples for the daily sets which meet the needs of feeding treatment in the case of different stages of disease. It is recommended that the nomenclature of diet foods together with the examples should be used in other hospitals of the republic.

The patients nutritional counselling must consider a systematized list of diets. This created system allows achieving individual patient's counselling which considers the patient's disease, the type of body build and the peculiarities of metabolism, the made clinical analyses. The codified system of ordinary foods and diets has been installed into the database (e-HL, electronic Health in Tartu University Hospital) which takes into consideration the specific features of treatment and the nutritional needs of the hospital and outpatient departments.

\section{THE CATERING SERVICE}

This enables the catering service of the Tartu University Hospital to provide for the special needs of 17 clinics with about 1,000 patients every day. The share of the diet food is about $25-28 \%$. The electronic database contains the titles for diets according to each meal-time which have been compiled in the hospital. Personal menus are entered in the case history by the dietologist according to the special needs of the patient and the indications of the diet treatment. For all the foods there are recipes and the technology for preparing them which should guarantee food safety.

The author has participated in working out the part of the Regulation of the Ministry of Social Affairs dealing with feeding treatment (Regulation No 131 Estonian Ministry of Social Affairs, 14 November 2002) which used the new system of diets worked out by the author. By today the hospitals and care 
centres of the Republic of Estonia use the internationally recognized titles of diets together with clinical indications energy and basic nutrients (Kiisk 2002, Kiisk et al. 2008).

The normative values of the basic nutrients are in accordance with Estonian nutritional recommendations, the nutrition guidelines of the WHO Regional Office for Europe and with the Regulation number 131 Health Protection Requirements for Nutrition in Health Care and Social Welfare Institutions, issued No 14 November 2002 by the Estonian Minister of Social Affairs.

Supplement: The nomenclature of diets includes ordinary food and eight groups of diet food with subgroups (Table 1).

Table 1. Nomenclature of diets kitchen in Tartu University Hospital

\begin{tabular}{|c|c|c|}
\hline & NOMENCLATURE OF DIETS KITCHEN* & \\
\hline I. & Ordinary Food & TAV \\
\hline \multirow[t]{8}{*}{ II. } & 1. Light Food or Basic Diets & $\mathrm{D}$ \\
\hline & 2. Non-lacking Diets & PV \\
\hline & 3. Gluten free Diets & G \\
\hline & 4. Purine lacking Diets & PUR \\
\hline & 5. High fibre Diets & KIU \\
\hline & 6. Protein rich Diets & VR \\
\hline & 7. Protein lacking Diets & VV \\
\hline & 8. Unflavoured Diets & MAG \\
\hline \multirow[t]{4}{*}{ III. } & 1. Diets for Diabetics ( $300 \mathrm{~g}$ carbochydrates) & 300 \\
\hline & 2. Diets for Diabetics ( $250 \mathrm{~g}$ carbochydrates) & 250 \\
\hline & 3. Diets for Diabetics ( $200 \mathrm{~g}$ carbochydrates) & 200 \\
\hline & 4. Diets for Diabetics ( $150 \mathrm{~g}$ carbochydrates) & 150 \\
\hline \multirow[t]{7}{*}{ IV. } & 1. Diets free of basic food allergens & AAT \\
\hline & 2. Lactose free Diets & LV \\
\hline & 3. Residue-lacking Diets & $\mathrm{JV}$ \\
\hline & 4. Diets for acute pancreatitis & P1 \\
\hline & 5. Diets for acute pancreatitis & P2 \\
\hline & 6. Diets for acute pancreatitis & P3 \\
\hline & 7. Postoperative Diets & $\mathrm{OP}$ \\
\hline \multirow[t]{3}{*}{ V. } & 1. Liquid Diets & VED \\
\hline & 2. Liquid Diets for Diabetics & SVE \\
\hline & 3. Gluten free liquid Diets & GVE \\
\hline \multirow[t]{2}{*}{ VI. } & 1. Soft Diets & PEH \\
\hline & 2. Soft Diets for Diabetics & SVE \\
\hline \multirow[t]{2}{*}{ VII. } & 1. Sandardised tube food & $\mathrm{R} 1 \ldots \mathrm{R} 5$ \\
\hline & 2. Special tube food & $\mathrm{R} 6 \ldots \mathrm{R} 8$ \\
\hline VIII. & 1. Baby Formula & $\mathrm{B}$ \\
\hline
\end{tabular}




\section{CONCLUSIONS}

1. The New System and nomenclature of new modern treatment diets was used in Tartu University Clinics in Tartu since 1995-1997. By today the activities of the Tartu University Hospital in the field of nutrition have been reorganised in connection with the introduction of the electronic case history in the years 2008-2009. It is recommended that the nomenclature of diet foods together with the examples should be used in other hospitals of the republic.

2. Intensive nutritional individual counselling was implemented for studied patients considering of body composition parameters, the intake of nutrients as well as laboratory data by a dietitian. Interviews have revealed that $98 \%$ of patients were satisfied with the appearance, size and taste of their food portions. The patients were also satisfied with diet foods. Dieticians and other specialist doctors have organised refresher courses for the kitchen staff.

3. The operation of the organisation is coordinated by a service manager and a product manager. This enables the catering service of the Tartu University Clinic to provide for the special needs of 17 clinics with about 1,000 patients every day. The share of diet food is about $25-28 \%$.

\section{REFERENCES}

1. Kiisk L., Kaarma H., Ots-Rosenberg M. (2008). Treatment diets in Estonian health care institutions. MEDICiNA, 44(8), 577-584.

2. Kiisk L., Rosenberg M. (2010). Toitumissoovitused kroonilise neeruhaiguse süvenemise ennetamisel. Tartu Ülikooli Kirjastus. In Estonian.

3. Kiisk L. (2002). Ravitoitlustamine. Tartu. In Estonian.

4. NutriData toitumise uurimise programm. NutriData Food Composition Database: (1) Food composition database; (2) Dietary analysis programme; (3) Dietary survey database (2014). Estonian National Institute for Health Development. Version of 6, 2. In English, Estonian and Russian. www.nutridata. ee

5. Pokrovski A., Samsonova M. (1981). Справочник по диетологии. [Spravočnik po dietologii.] Medicina. In Russian.

6. Regulation No. 131. Estonian Ministry of Social Affairs. Health Protection Requirements for Nutrition in Health Care and Social Welfare Institutions. Tervisekaitsenõuded toitlustamisele tervishoiu- ja hoolekandeasutuses (2002).

7. Roos G., Lean M., Anderson A. (2002). Dietary interventions in Finland, Norway and Sweden: nutrition policies and strategies. J Hum Nutr Diet, 15(2), 99-100. 
8. Nordic Nutrition Recommendations 2012. Integrating nutrition and physical activity. $5^{\text {th }}$ edition. Nordic Concil of Ministers (2014). Nordisk Ministerrad. www.norden.org

9. Fineli. Elintarvikkeiden koostumustietopankki. Finnish Food Composition Database. Special Diets. National Institute for Health and Welfare 2003-2015. www.fineli.fi

10. Kiisk L., Ots-Rosenberg M., Kaarma H. (2010). Pecularities of Nutrition of Kidney Transplant Patients. Papers on Anthropology, XIX, 180-202.

11. Ryan K.J., Casas J.M., Mash L.E., McLellan S.L., Lloyd L.E., Stinear J.W., Plank L.D., Collins M.G. (2014). The effect of intensive nutrition interventions on weight gain after kidney transplantation: protocol of a randomised controlled trial. BMC Nephrol, 15, 148.

\section{Address for correspondence:}

Liidia Kiisk MD

Tartu University Hospital, L. Puusepa Street 8

E.mail: Liidia.Kiisk@kliinikum.ee 